\title{
THE IMPACT OF ICT BASED LEARNING IN TERTIARY INSTITUTIONS IN NIGERIA
}

\author{
Chilaka Longinus Udochukwu \\ Department of Computer Science \\ Imo State University, Owerri \\ Alphonsus Onyekachi Agbakwuru
Department of Computer Science
Imo State University, Owerri
}

\author{
Njoku Donatus Onyedikachi \\ Department of Computer Science \\ Federal University of Technology, Owerri \\ Akhigbemidu Ozemoya Rex \\ Department of Computer Science \\ Alvan Ikoku Federal College of Education, \\ Owerri
}

\begin{abstract}
This study sought to evaluate the impact of ICT based learning in tertiary institutions in Nigeria. Participants numbering 60 were randomly selected from three tertiary institutions in Imo State, Nigeria. A wellstructured questionnaire was administered to each respondent. The respondents were asked to respond to a range of options based on their opinion on the item before them in terms of awareness/knowledge necessary for the use of ICT facilities for learning, staff and students' attitude to the use of ICT based learning tools in teaching and learning, ICT facilities and equipment in tertiary institution, and the prospect of ICT based learning. The obtained data was analyzed using simple statistical tool. The findings indicated generally that the majority of the staff and students who participated strongly agreed from their responses on the prospects of ICT that it will impact positively to the growth and development of tertiary education in Nigeria.
\end{abstract}

Keywords - ICT, Learning, teaching, Tertiary Institutions

\section{INTRODUCTION}

The use of Information Communication Technology (ICT) for the purpose of study to enhance and support teaching and learning process in tertiary institutions in Nigeria is becoming increasingly popular. It is a forming of learning known as electronic leaning (or e-learning). The ICT based learning involves the way students and teachers (stakeholders) in the education sector share study materials or other related academic information or knowledge using electronic mailing (e-mail), social media network, multi-media messages, SMS, voice call, and other interactive application platform using electronic devices. The learning can be in form of teleconferencing, social network group chat, online interactive class among students, or among students and their teacher, or among professionals (academic staff). A generalized definition of ICT has been presented by UNESCO in Egoeze et al.
(2018) as a range of hardware equipment -personal computer, scanners, digital camera; software -database programme, multi-media programme; and telecommunication infrastructure -phones, faxes, videoconferencing equipment, and web cameras, which enable us to access, retrieve, store, organize, operate, present, send material and communicate locally and internationally through digital media (Egoeze et al., 2018) The application of ICT based learning provides students easy access to learning materials including doing their course work online.

All over the world, including Nigeria, developments in ICT have changed and impacted higher education in several ways such as increasing access to learning material, improving and ensuring that educational resources are available, enabling meaningful discussions and communications among the learned and the learners, out-dating the traditional educational system and ensuring that students are better prepared for the contemporary society, and or hasten the national development efforts. ICT teaching and learning technology is being adopted in higher education institutions all over the world a way to create environment for both students and their instructors to take part in shared learning and gain access to information. Ahmed (2009) has asserted that the use of ICT makes administrative and teaching process more flexible, reduced running time, and more cost effective, and as such, most of the universities are trying tap into the benefits of ICT.

In recent times, some institutions in Nigeria are adopting the use of ICT to promote distance learning or education, which is called e-learning. E-learning has been described as means of delivering education and training applications, monitoring the performance of learner and report the progress of learner using electronic technology. ICT can be described as a computer based innovative learning process for providing electronically enabled, well-designed, learner-centred and interactive learning environments to any person, anywhere, whenever by using the ICT tools (comprising of internet and digital technologies) with respect to instructional design ethics. Hence, it is an e-learning approach that is based on the use of 


\section{International Journal of Engineering Applied Sciences and Technology, 2019 Vol. 4, Issue 2, ISSN No. 2455-2143, Pages 1-6 \\ Published Online June 2019 in IJEAST (http://www.ijeast.com)}

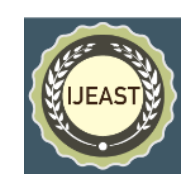

computers online or offline. In the online learning, the learner is linked up with a discussion or interactive platform via the internet. In the offline, the learner can be made to interact with documented discussion or interaction, in the form of typed (or written) document, video or audio lectures contained in a storage device like CD-ROM, Flash Drive, memory card, etc. This follows with the statement that the various ICT products available and having usefulness to education like teleconferencing, email, audio conferencing, television lessons, radio broadcasts, interactive radio counseling, interactive voice response system, audiocassettes and CD ROMs etc have been apply for different educational purposes (Noor-UI-Amin, 2013; Sharma, 2003; Sanyal, 2001; Bhattacharya and Sharma, 2007).

The use of stored lecture note on CD-ROM and other storage devices like flash drive is common among tertiary institutions in Nigeria which is accessed or utilized offline at the convenience of the learner. However, the challenge with this approach is that it not interactive like the class room learning. Some institutions have implemented online learning by using internet facilities. Nevertheless, this method has not well deployed and sustained for effective e-learning purpose due to unavailability of stable and reliable network. Another challenge to the full adaptation of the online learning is due to erratic and inconsistent power supply problem and high cost of running power generating set. Though most of the tertiary institutions in Nigeria have started putting in place ICT centres that will provide internet services within and around the campus, the main idea is to carry out other educationally based online services like result checking, online registration, payment of school fee etc. without much concern towards deploying the centre for e-learning purpose. For this reason, students of tertiary institutions in Nigeria are often made to resort to the use of cyber café to carry out must of their academic assignments and tasks.

In Nigeria, some tertiary institutions are using the ICT base technology to promote learning. Presently many of the universities in Nigeria have digital library that aid students to carry out their research and access recent publications online. Tutors in higher institutions are now delivering their lectures based power point presentation using computer and projectors and are also encouraging their students to do same in their discussion class and paper presentations. Digital classrooms and workshops are becoming prominent some tertiary institutions in Nigeria. This supports the assertion by Awoleye (2006) that ICT provides easy communication, it serves as a research tool, and provides solutions to study tasks or assignments. Hence, ICT is fast gaining access as an integrative part of policies and plans of national higher education across the world (Louw et al. 2009).

The objective of this paper is to find out the impact of ICT base study in tertiary institutions in Nigeria. The study has been confirmed to three selected tertiary institutions in Imo State, Nigeria. In order to realize the objective of this study, the remaining of part this paper has been divided into four section: literature review, methodology, result and discussion, conclusion, and recommendation.

\section{RELATED WORK}

Egoeze et al. (2018) studied the impact of ICT on universities administrative and management activities. The authors observed from their findings that admissions, registration, and payment of fees seemed to be the major areas ICT has become increasingly deployed and impacted on administrative services/management of students' records in Nigeria universities. Adeoye et al. (2013) in their study to appraise the role of ICT as an agent of change for higher education in Nigeria, stated that use of ICT has absolutely impacted on the quality and quantity of teaching, learning and research in Nigerian tertiary education institutions. A study to establish performance expectancy, effort expectancy, social influence and facilitating conditions relate $d$ to use of ICT by undergraduate students was presented by Bakkabulindi et al. (2015). The authors used descriptive analysis and Multiple Regression tools, and observed from their findings that expectancy effort and facilitating conditions significantly positively correlated with the use of ICT. The implication of this, the authors maintained, is that ICT agents such as the support department in university should acquire ICTs facilities that are user friendly and focused more on improving perceived compatibility of ICT. Oni and Uko (2016) examined the utilization of ICTs as teaching aids in higher education institutions in Nigeria. The authors stated from their findings that though ICT facilities were available, especially the mobile phones and internet, it use has not been fully integrated into teaching and learning process. Olaore (2014) examined the impacts of ICT on education in Nigeria. The observed that though ICT may impact positively on education but the manner at which is being taught and presented in a larger effect than its use. Also, the approach of the educational establishment can affect the effectiveness of ICT. An investigation based on pragmatic evaluation of the role of ICT in advancement of teaching and learning was presented by Ezugwu et al. (2016). Although authors observed certain challenges that affect the use of ICT in the university, the results obtained indicated that lecturers in the considered university supports the use of ICT in teaching and learning because of the important role it provides in promoting efficiency in teaching process. Noor-UI-Amin (2013) presented an effective use of ICT for education and learning based on literature review. The author stated that the use of ICT in education offered a more student-centred learning setting.

Some notable facts about ICT based learning in tertiary institutions are presented below.

\section{A. The strength of ICT Learning}

The concept of ICT based learning on the use of electronic technology to provide quality and affordable education to the 


\section{International Journal of Engineering Applied Sciences and Technology, 2019 \\ Vol. 4, Issue 2, ISSN No. 2455-2143, Pages 1-6 \\ Published Online June 2019 in IJEAST (http://www.ijeast.com)}

reach of larger population in the society regardless of background and status. Hence, the strength of ICT application in tertiary education and academic works are demonstrated in the following areas:

a) Online examination: the ICT facilities enable students to take examination using internet platform irrespective of their locations. This is also known as electronic examination (e-examination).

b) Computer based drills: computer aided programmes (software packages) with animations and interactive platform are created to provide study environment that is effective and dynamic for students to learn. This is known as electronic drill (e-drill).

c) Online book: this is known as e-book. E-books are available online and are mostly found in digital library. A student course content can be in form of e-book and documented online for easy access and use.

d) Online counselling: the use of ICT base technology to provide academic counselling has become increasingly common. It is common these days to have students and their academic course counsellors or lecturers interact via social media platform, mobile phone communication etc. Teleconferencing are also used among senior academic /non-academic staff and research groups. This gives room for the students to ask questions without being subjected to undue pressure or anxiety.

e) Electronic sound (e-sound) book: this uses ICT based technology -internet facilitated, to provide electronic aided book that supports students especially the visually impaired. The student listens to their study material (course book) contents online.

\section{B. Importance of ICT in Tertiary Institutions}

a) ICT education can enable broader participation and fair access to acquire higher education by providing the students (learners) the opportunity to start learning and to select courses and necessary support in terms of the students' requirements.

b) ICT can provide a virtual environment that supports students to take innovative and creative learning with others by the means of simulations of real time events, online programmes, or teamwork with other researchers and education providers.

c) ICT can offer personalized learning experience for all students, including the physically challenged, those in remote or far distance location from their institutions of learning.

d) ICT based learning offers the opportunity for a range of academic tools that can motivate and encourage teachers and students to become creative, innovative and resourceful. e) ICT provides the opportunity for stakeholders in educational sector from different institutions of higher learning to form online research communities where innovative and creative ideas are easily shared.

f) ICT promotes healthy and robust competition among professionals and experts in various intuitions of higher education globally.

g) ICT can facilitate easy and direct access relationship between tertiary institutions and industries, which can lead to immediate transformation of research works into real world application.

h) ICT can eliminate barriers to academic excellence by making available new and creative ways of encouraging and engaging staff and students so that everyone can be inspired to attain their educational potentials.

\section{Challenges of ICT in Tertiary Institutions in Nigeria}

a) The cost of purchasing and installing ICT gadgets/facilities is high.

b) The cost of networking and data transmission is on a high side.

c) The cost of managing ICT centre so that it provide stable network and access to internet is expensive.

d) Implementation and management of ICT centres in tertiary institutions in Nigeria still suffers from dearth of skilled manpower.

e) Staff in institutions of higher learning are inadequately trained and are not well exposed to recent digital technology.

f) Unstable power supply generally affects the efficiency of work in all sectors of the economy including the ICT. This also holds in the management and maintenance of ICT facilities in tertiary institutions in Nigeria.

g) Literacy and ICT compliance level among staff and students appears to be low especially in the area of research and training.

h) Telecommunication infrastructures in Nigeria are still not adequate and reliable enough to support efficient elearning programme.

\section{METHODOLOGY}

In this paper, descriptive research and enquiring technique using a well-structured questionnaire was used for data collection. This is because the study is descriptive in nature. Three tertiary institutions of higher education in Imo state were randomly selected. A total of 60 respondents in tertiary institution were randomly selected across the various institutions considered. The participants were drawn from academic staff and students. Data was obtained from academic staff, 20 drawn among lecturers from the different tertiary 
institution as well as 40 full time undergraduate and postgraduate students.

The participants were made to state respond to the following list of items:

1. Awareness/knowledge necessary for the use of ICT facilities for learning.

2. Staff and students attitude to the use of ICT based learning tools in teaching and learning.

3. ICT Facilities and Equipment in tertiary institution

4. Prospect of ICT based learning

\section{RESULTS AND DISCUSSION}

\section{A. Results}

Table 1. Awareness/knowledge of use of ICT facilities for learning

\begin{tabular}{|l|l|l|l|}
\hline S/N & Item & $\begin{array}{l}\text { Yes } \\
(\%)\end{array}$ & $\begin{array}{l}\text { No } \\
(\%)\end{array}$ \\
\hline 1 & $\begin{array}{l}\text { Do you have any internet enable device such as } \\
\text { PC, Laptop or mobile internet support gadget? }\end{array}$ & 85 & 15 \\
\hline 2 & Do you have active email address? & 90 & 10 \\
\hline 3 & $\begin{array}{l}\text { Do you know how to operate ICT device } \\
\text { effectively to access the internet? }\end{array}$ & 75 & 25 \\
\hline 4 & $\begin{array}{l}\text { Do you often use ICT device for educational } \\
\text { purpose? }\end{array}$ & 60 & 40 \\
\hline 5 & $\begin{array}{l}\text { Do you prefer online learning/training to } \\
\text { conventional classroom learning? }\end{array}$ & 55 & 45 \\
\hline
\end{tabular}

Table 2. Staff and students attitudes to the use of ICT learning tools

\begin{tabular}{|l|l|l|l|l|l|}
\hline S/N & Item & A & SA & DA & SDA \\
\hline 1 & $\begin{array}{l}\text { Inability to effectively operate ICT } \\
\text { devices makes e-learning tedious. }\end{array}$ & 17 & 35 & 8 & - \\
\hline 2 & $\begin{array}{l}\text { Some staff and students do not } \\
\text { know how to use ICT tools for } \\
\text { learning purpose. }\end{array}$ & 20 & 33 & 7 & - \\
\hline 3 & $\begin{array}{l}\text { Inequality of access to technology } \\
\text { is an earlier challenge to ICT base } \\
\text { learning in tertiary institution. }\end{array}$ & 25 & 35 & - & - \\
\hline 4 & $\begin{array}{l}\text { Students of tertiary institutions in } \\
\text { Nigeria are not allowed to have } \\
\text { easy access to available internet } \\
\text { facilities in school. }\end{array}$ & 17 & 43 & - & - \\
\hline 5 & $\begin{array}{l}\text { Students spend most of their time } \\
\text { online engaging and making new } \\
\text { friends rather than spend it doing } \\
\text { their assignment. }\end{array}$ & 25 & 35 & - & - \\
\hline
\end{tabular}

Note: Agree (A), Strongly Agree (SA), Disagree (D), Strongly Disagree (SD)

Table 3. Facilities and equipment for ICT learning in tertiary institutions
\begin{tabular}{|l|l|l|l|l|l|}
\hline S/N & Item & A & SA & DA & SDA \\
\hline 1 & $\begin{array}{l}\text { Students are restricted from } \\
\text { using available ICT tools in } \\
\text { tertiary institution. }\end{array}$ & 29 & 10 & - \\
\hline 2 & $\begin{array}{l}\text { ICT learning facilities and } \\
\text { equipment in tertiary institutions } \\
\text { are not often replaced with latest } \\
\text { technology. }\end{array}$ & 20 & 33 & 7 & - \\
\hline 3 & $\begin{array}{l}\text { Tertiary institutions lack } \\
\text { adequate ICT tools to support } \\
\text { online learning }\end{array}$ & 25 & 35 & - & - \\
\hline 4 & $\begin{array}{l}\text { Inadequate financial provision } \\
\text { hinders improvement in ICT }\end{array}$ & 27 & 33 & - & - \\
\hline
\end{tabular}

\begin{tabular}{|l|l|l|l|l|l|}
\hline & learning. & & & & \\
\hline 5 & $\begin{array}{l}\text { Available ICT equipment and } \\
\text { facilities are not well maintained. }\end{array}$ & 25 & 35 & - & - \\
\hline
\end{tabular}

Table 4. Prospects of ICT learning in tertiary institutions

\begin{tabular}{|c|c|c|c|c|c|}
\hline $\mathbf{S} / \mathbf{N}$ & Item & A & SA & DA & SDA \\
\hline 1 & $\begin{array}{l}\text { ICT based learning } \begin{array}{r}\text { can } \\
\text { overcome barriers }\end{array} \\
\text { geographical location to teaching } \\
\text { and learning. }\end{array}$ & 29 & 31 & 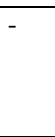 & 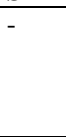 \\
\hline 2 & $\begin{array}{l}\text { The aim and objectives of } \\
\text { tertiary education can be } \\
\text { achieved more efficiently with } \\
\text { ICT based learning. }\end{array}$ & 23 & 37 & - & - \\
\hline 3 & $\begin{array}{l}\text { Tutors and learners in tertiary } \\
\text { institutions can easily evaluate } \\
\text { themselves using ICT based } \\
\text { educational tools. }\end{array}$ & 25 & 35 & - & - \\
\hline 4 & $\begin{array}{l}\text { ICT based learning can provide } \\
\text { flexibility and remove inequality } \\
\text { because it can be accessed } \\
\text { anytime, anywhere and by } \\
\text { anyone. }\end{array}$ & 25 & 35 & - & - \\
\hline 5 & $\begin{array}{l}\text { With ICT based learning, } \\
\text { innovative and creative learning } \\
\text { and teaching is possible. }\end{array}$ & 27 & 33 & - & - \\
\hline 6 & $\begin{array}{l}\text { ICT promotes collaborations } \\
\text { among research institutions. }\end{array}$ & 17 & 43 & - & - \\
\hline
\end{tabular}

\section{A. Discusssion}

From the data presented in Table 1, it is obvious that $90 \%$ of the respondents agreed that they have email address, $85 \%$ of the respondents agreed have PC, laptop or mobile internet support gadget, $75 \%$ of the respondents affirmed that they can effectively operate ICT devices to access the internet, $60 \%$ of the respondents often used ICT device for education purposes, and $55 \%$ preferred online learning/training to conventional classroom learning. These are popular responses from the participants.

The responses concerning staff and students to the use of ICT learning tools in Table 2, majority of the respondents (72\%) strongly agree that students are not allowed access to internet facilities in tertiary institutions in Nigeria. Popular responses indicated that $58 \%$ of the respondents strongly agreed that inability to effectively operate ICT make elearning tedious, inequality of access to technology is a prior challenge to ICT base learning in tertiary institution, and students spend most of their time online engaging and making new friends rather than spend it doing their assignment. 55\% of the respondents strongly agreed that some staff and students do not know how to use ICT tools for learning purpose.

From Table 3, most popular views indicated that: $48 \%$ of the respondents agree that available ICT tools in tertiary institutions in Nigeria are not made available to the students. $55 \%$ of the respondents strongly agree that ICT learning facilities and equipment in tertiary institutions are not often replaced with latest technology. $58 \%$ of the respondents strongly agree that tertiary institutions lack adequate ICT tools 


\section{International Journal of Engineering Applied Sciences and Technology, 2019 Vol. 4, Issue 2, ISSN No. 2455-2143, Pages 1-6 \\ Published Online June 2019 in IJEAST (http://www.ijeast.com)}

to support online learning. 55\% of the respondents strongly agree that inadequate financial provision hinders improvement in ICT learning. 58\% strongly agree that available ICT equipment and facilities are not well maintained.

So far, the findings revealed the feelings of the stakeholders in the tertiary institutions concerning the use of ICT facilities and equipment in carrying out learning and teaching. The participants, through their responses, indicated that the awareness/knowledge of use of ICT facilities for learning is high among staff and students. The attitudes of staff and students to the use of ICT are not impressive. There are challenges using available ICT tools in tertiary institutions as majority of the respondents strongly agreed that access are not given to effectively use them for learning and teaching.

From Table 4, There is general acceptance that ICT based learning will profit tertiary institutions in Nigeria. Hence, the popular belief is as follows: $72 \%$ respondents strongly agreed that ICT promotes collaborations among research institutions, $58 \%$ of the respondents strongly agreed that tutors and learners in tertiary institutions can easily evaluate themselves using ICT based educational tools and the same is true for those who strongly agreed that ICT based learning can provide flexibility and remove inequality because it can be accessed anytime, anywhere and by anyone. 55\% of the respondents strongly agreed that the aim and objectives of tertiary education can be achieved more efficiently with ICT based learning. 55\% of the respondents strongly agreed that with ICT based learning, innovative and creative learning and teaching is possible and $52 \%$ of the respondents strongly agreed that ICT based learning will eliminate the issue of geographical location to teaching and learning. In fact, there is no respondents that disagree or strongly disagree that ICT will benefit tertiary education in Nigeria.

\section{CONCLUSION}

This paper has presented the Impact of ICT based learning in tertiary institutions in Nigeria. The study seek the general opinion of stakeholders from three randomly selected tertiary institutions in south eastern Nigeria. The respondents were asked to respond to a range of options based on their opinion on the item before them in terms of awareness/knowledge necessary for the use of ICT facilities for learning, staff and students' attitude to the use of ICT based learning tools in teaching and learning, ICT facilities and equipment in tertiary institution, and the prospect of ICT based learning. The general response on the prospect of ICT in tertiary education indicated that tertiary education can be more dynamic and efficient in providing robust collaborative learning. From the data obtained, the following recommendations are made:

a) Staff and students in tertiary institutions should be encouraged to acquire the necessary skills to operate and use ICT facilities and equipment in carrying out e-learning. b) The inequality in the spread of ICT gadgets in the larger society should be addressed by the government and stakeholders in ICT sector of the economy.

c) The management of tertiary institutions in Nigeria should endeavour to grant access to students to available internet network on campus. This will motivate the students to do their assignment using ematerials online.

d) Outdated ICT facilities and equipment should be replaced with modern technology.

e) The government should endeavour to provide funds to tertiary institutions for the purchase of ICT equipment. Also, the management of tertiary institutions in Nigeria should be able to generate fund internally and channel some percentage to funding ICT learning.

f) The culture of maintenance should be adopted by management of tertiary institutions to ensure that the available ICT facilities and equipment are always in good working conditions.

g) There should be sensitization of staff and students on the use of digital library for research and learning purposes.

A strict adherence to the suggestions/recommendations above will be worthwhile.

\section{ACKNOWLEDGEMENT}

Authors appreciate the respondents for the responses and providing the information necessary to effectively carry out this study.

\section{REFERENCES}

1. Adeoye Y.M., Oluwole A. F., and. Blessing L. A. (2013) Appraising the role of information communication technology (ICT) as a change agent for higher education in Nigeria, International Journal of Educational Administration and Policy Studies, Vol. 5, No. 8, pp. 177-183.

2. Ahmed J. U. (2009). Use of ICT in the private universities of Bangladesh, International journal of educational administration, Vol. 1, No. 1, $77-82$.

3. Bakkabulindi F. E. K., Mugagga A. M., Shopi J. M., \& Kabasiita J. (2015). Application of the Unified Theory of Acceptance and use of Technology to the use of ICT by Undergraduates in the School of Education, Makerere University, African Higher Education Review (AHER), Vol. 9 No. 1\&2, 4-17.

4. Bhattacharya I., and Sharma K. (2007). India in the knowledge economy - an electronic paradigm, International Journal of Educational Management Vol. 21 No. 6, pp 543- 568.

5. Egoeze F., Misra S., Maskeliūnas R., and Damaševičius R. (2018). Impact of ICT on 
Universities Admininstrative Services and Management of Students Records: ICT in University Administration, International Journal of Human Capital and Information Technology Professionals, Vol. 9, No. 2, 1-16.

6. Ezugwu A. E., Ofem P. O., Rathod P., Agushaka J. O., and Haruna S. (2016). An Empirical Evaluation of the Role of Information and Communication Technology in Advancement of Teaching and Learning, 2nd International Conference on Intelligent Computing, Communication \& Convergence (ICCC2016), Procedia Computer Science 92, 568 - 577.

7. Louw J., Brown C., Muller J., and Soudien C. (2009). Instructional technologies in social science instruction in South Africa, Computers \& Education, 53(2), 234-242.

8. Noor-Ul-Amin S. (2013). An Effective use of ICT for Education and Learning by Drawing on Worldwide Knowledge, Research, and Experience: ICT as a Change Agent for Education (A LITERATURE REVIEW), Scholarly Journal of Education, Vol. 2, No. 4, 38-54.

9. Olaore I. B. (2014). The Impacts (Positive and Negative) of ICT on Education in Nigeria, Developing Country Studies, Vol.4, No.23, 154-156.

10. Oni A., and Uko E. S. (2016). Utilisation of ICTs as Teaching Aids in Two Higher Education Institutions in Lagos, Makerere Journal of Higher Education, Vol. 8, No. 2, $129-138$.

11. Sanyal B. C. (2001). New functions of higher education and ICT to achieve education for all. Paper prepared for the Expert Roundtable on University and Technology-for- Literacy and Education Partnership in Developing Countries, International Institute for Educational Planning, UNESCO, Paris.

12. Sharma R. (2003). Barriers in Using Technology for Education in Developing Countries, IEEE0-78037724-9103. Singapore schools', Computers \& Education Vol .41, No. 1, pp 49-63. 